\title{
Effect of Antimicrobial Edible Coatings on Quality and Shelf Life of Minimal Processed Guava (Psidium guajava)
}

\author{
Mona A. Elabd \\ Food Engineering and Packaging Department, Food Technology Research Institute, \\ Agricultural Research Center, Giza, Egypt
}

Received: 27 February, 2018

Revised: 10 May, 2018

Accepted: 28 May, 2018

\begin{abstract}
The present study aimed to develop an antimicrobial edible coating and to evaluate their efficiencies in preserving guava slices. Guava slices were submitted to four treatments: without coating (control) A, coating with potato starch containing $0.25 \%$ or $0.5 \%$ chitosan, B and C treatments respectively, and coating with $3 \%$ potato starch, $1.5 \%$ ascorbic acid and $0.2 \%$ potassium sorbate, D treatment. All samples were stored in refrigerator at $4 \pm 1{ }^{\circ} \mathrm{C}$ and $70-75 \%$ relative humidity for 18 days. The following characteristics were analyzed: weight loss, firmness, total soluble solids, total titratable acidity, vitamin C, polyphenol oxidase (PPO), catalase (CAT), microbial quality and sensory attributes. Treatments with edible coatings were effective in reducing weight loss and maintaining texture of guava slices. The coatings decreased the increase in total soluble solids and decreased the loss in total titratable acidity compared to the uncoated ones. The lowest activity values of enzymes (PPO and CAT) were recorded for coated samples. The use of edible coatings contributed in reducing microbial growth of guava slices and increasing their shelf-life.
\end{abstract}

Key words: Edible coating, guava slices, shelf-life.

\section{INTRODUCTION}

Guava fruit (psidium guajava L.) is a vital source of vitamins, minerals, antioxidants and dietary fibers (Hassimotto et al., 2005, Adrees et al., 2010). Highly perishable nature and proning towards chilling injury, diseases, insect-pests and physical damage are the main drawbacks of guava fruit after harvesting. However, during postharvest period, this fruit rapidly start senescence, a fact which prevents it from being stored for long period. This is a very serious problem, because it hinders or even prevents the commerce of this fruit to distant markets. Therefore, the application of postharvest technology is essential for guava fruit marketing (Lima et al., 2002).

On the other hand, due to its climacteric nature, the fruit ripens rapidly and hence highly perishable, with a very short shelf life ranging from 2-3 days at room temperature (Bassetto et al., 2005).

Minimal processing of fresh-cut fruits, which involves grading, washing, sorting, peeling, slicing and packaging, can affect the integrity of the fruits and cause biochemical changes and microbial spoilage that may result in degradation of the colour, texture and flavour of fruits (Watada \& Qi, 1999). The removal of the natural protective skin of fruits caus- es leakage of juices and sugars from the damaged tissue resulting in the fruits being highly susceptible to microbial spoilage (Oms-Oliu et al., 2010). For such aspects the performance of packaging materials are quite important and depend on their efficiency to reduce transfering between foodstuff and the environment such as the transport of volatile compounds from food to the outer atmosphere or from the surrounding medium to the packaged product, and the adsorption of volatile compounds at the surface of the packaging (sorption or scalping) (Reineccius, 1991, Benet et al., 1992, Blumental, 1997). An edible coating can be used as an alternative to modified atmosphere packaging to improve the shelf life of fresh-cut fruits (Rojas-Grau et al., 2009). Moreover, coatings are effective barriers to water loss, provide good appearance and brightness, making fruits and vegetables more attractive to the market (Lemos et al., 2007, Vila et al., 2007).

Due to the strict regulation on chemical use in food production, the replacement of the traditional chemical fungicides by natural antimicrobial substances is a favorable factor for the acceptance of agricultural products in the international market (Raybaudi-Massilia et al., 2007). Chitosan, which may be used as a biofilm, by itself or associated to other compounds, was very effective in inhibiting 
microorganisms during the postharvest life of vegetables and fruits, and also in minimally processed food (Liu et al., 2007). Chitosan is a biopolymer of high potential to be used as an edible coating and active package, because it is non-toxic, able to form biodegradable films and prevents antimicrobial activity. Among edible coatings, chitosan, also has long been known to protect perishable produce from deterioration by reducing transpiration, respiration and maintaining the textural quality. Chitosan \{poly $\beta$-(1-4) $N$-acetyl-d-glucosamine\}, a deacetylated form of chitin, is a natural compound obtained from crustacean shells (crabs, shrimp and crayfishes) either by chemical or microbiological processes and can be produced by some fungi (Tan et al., 1996). Indeed, chitosan is often considered to be the ideal preservative coating for fresh fruits because of its excellent film-forming and biochemical properties (El-Ghaouth et al., 2000).

In this context, the objectives of this work were to develop edible coatings based on potato starch and chitosan or potassium sorbate to be used on the surface of guava slices and to evaluate their preservation efficiencies through microbiological and physicochemical analyses. Shelf life and quality of guava slices were also taken into consideration in this respect.

\section{MATERIAL AND METHODS}

\section{Sample preparation}

Guava fruit harvested at commercial maturity was obtained from the local market. Good quality fruit was selected for uniformity of size and colour. Fruit was washed and cut into slices. The guava slices were dipped in chlorinated water $(150 \mathrm{ppm})$ for three $\mathrm{min}$. and drained for $10 \mathrm{~min}$. This was followed by air drying for $3 \mathrm{~min}$, and randomly divided into four groups, which corresponded to three coating treatments, and one water dipped control.

\section{Coating materials}

Potato starch was obtained from Leader Factory for chipsy, Tanta city. Preliminary treatment of potato starch (PS) was achieved using the method of Elabd (2013). Chitosan was purchased from Mifad Company, Badr city, Egypt. Ascorbic acid and potassium sorbate were purchased from ElGomhoria Co. for chemical and drugs.

\section{Coating treatments}

Fruit slices groups were assigned to the follow- ing coating treatments: A [non-coated (control)]. B [ $3 \%$ PS and $0.25 \%$ chitosan], C [ $3 \%$ PS and $0.5 \%$ chitosan], D [3\% PS, $1.5 \%$ ascorbic acid and $0.2 \%$ potassium sorbate]. Glycerol was added as plasticizer $(50 \% \mathrm{w} / \mathrm{w})$ in all the previous coating solutions. Preparation of chitosan solution was done according to the method of Jiang \& $\operatorname{Li}$ (2001), then was added to the solutions (B and C) and gradually heated to $70^{\circ} \mathrm{C}$ while stirring until gelatinization was attained. After gelatinization of coating solution (D), it was cooled and ascorbic acid and potassium sorbate were added (Nasution et al., 2015). Experiment was conducted in three replications.

\section{Coating procedure of fruit slices}

Guava slices samples were dipped for $1 \mathrm{~min}$ in antibrowning solution composed of a mixture of $1 \%(\mathrm{w} / \mathrm{v}) \mathrm{L}-$ ascorbic acid and $1 \%(\mathrm{w} / \mathrm{v})$ citric acid. The excess liquid was gently removed by drying for 3 min using a fan to ensure dryness. This was followed by dipping in $2 \%(\mathrm{w} / \mathrm{v})$ calcium chloride solution as solidifying agent. The slices were immersed in different coating solutions for $3 \mathrm{~min}$ and dried. The slices then were stored in refrigerator at $41 \pm{ }^{\circ} \mathrm{C}$ and relative humidity $70-75 \%$, for 18 days. The guava slices were analyzed on day zero and every 3 days, during storage period of 18 days.

\section{Physical and chemical analyses}

- Weight loss was measured as percentage of weight loss from the initial weight of slices (AOAC 2000).

- Total soluble solid (TSS) was determined in the juices by the refractometric method at room temperature using a polish manual refractometr (R R 12, Nr 05116, 0-35\% at $20 \mathrm{C}$ ) according to the method given in the AOAC (2000).

- Firmness of the fruit slices was measured using a hand dynamometer model FDP 1000 with a thump $(2 \mathrm{~mm})$ in gf (gram- force). The data were transformed into Newton units using $(\mathrm{N})$ standard factor (1 gram- force $=$ 0.00980665 Newton).

- Total titratable acidity (TTA) of the juices was determined as described in the AOAC (2000).

- Ascorbic acid (V.C) was determined using 2,6 dichlorophenolindophenol titrimetic method as described in the AOAC (2000). The results were expressed as mg ascorbic acid per 100 $\mathrm{g}$ of fruit. 
- Polyphenol oxidase activity was determined according to the method described by Malik \& Singh (1980) and Hafez (2010) using model UV-160A spectrophotometer (Shimadzu, Japan).

- Catalase activity (CAT) was determined spectrophotometrically according to Aebi (1984).

\section{Microbial analysis}

Total bacterial count (TBC) and count of yeasts and moluds (Y\&M) were determined according to the methods described in the DIFCO manual (DIFCO, 1977).

\section{Sensory evaluation}

It was carried out by trained panelists every three days, during storage period as described by Lawless \& Heymann (1999).

\section{Statistical analysis:}

This was carried out according to SAS (2010).

\section{RESULTS AND DISCUSSION}

\section{Weight loss}

Application of all coating treatments significantly decreased the weight loss of guava slices during storage period compared to the control. There was an added benefit to minimize of weight loss by increasing the concentration of chitosan from 0.25 to $0.5 \%$. The lowest weight loss was found in C coated sample followed by B and D then the uncoated sample (control) (Fig. 1). Freshcut guava slices are prone to weight loss due to the removal of skin and pulp that exposes the fruit's internal tissues (Watada \& Qi 1999). Loss weight in fresh fruit and vegetable is mainly due to the loss of water caused by transpiration and respiration processes (Zhu et al., 2008). Chitosan coating forms a layer of semi-transparent to smooth the pericarp surface (Dong et al., 2004). At the end of storage period, the lowest significant weight loss was recorded for $\mathrm{C}$ treatment $(17.44 \%)$ followed by $\mathrm{D}$ coating treatment $(18.26 \%)$.

\section{Total soluble solids}

The control sample presented a decrease in the TSS values during the experiment, while the coated treatments were significantly more effective in controlling the sugar content until the end of storage period. Fig (2) indicated that the TSS\% increased gradually throughout the storage periods. It reached the highest percentage at the end of storage period. However, no significant differences were detected

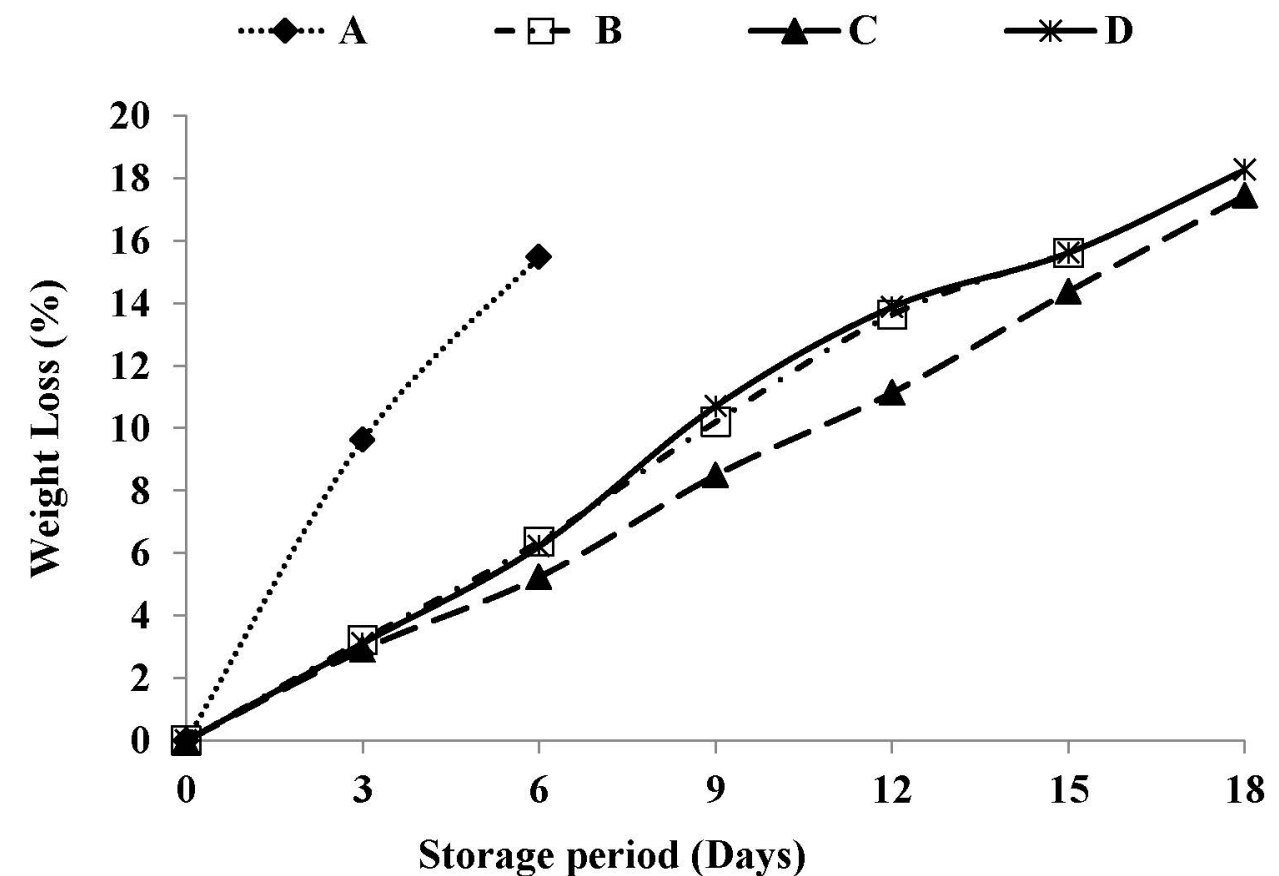

Fig. 1: Effect of coatings on weight loss (\%) of guava slices during storage at $4 \pm 1^{\circ} \mathrm{C}$. A: Control, B: sample treated with $3 \%$ potato starch and $0.25 \%$ chitosan, $C$ : sample treated with $3 \%$ potato starch and $0.5 \%$ chitosan, D: sample treated with $3 \%$ potato starch, $1.5 \%$ ascorbic acid and $0.2 \%$ potassium sorbate 


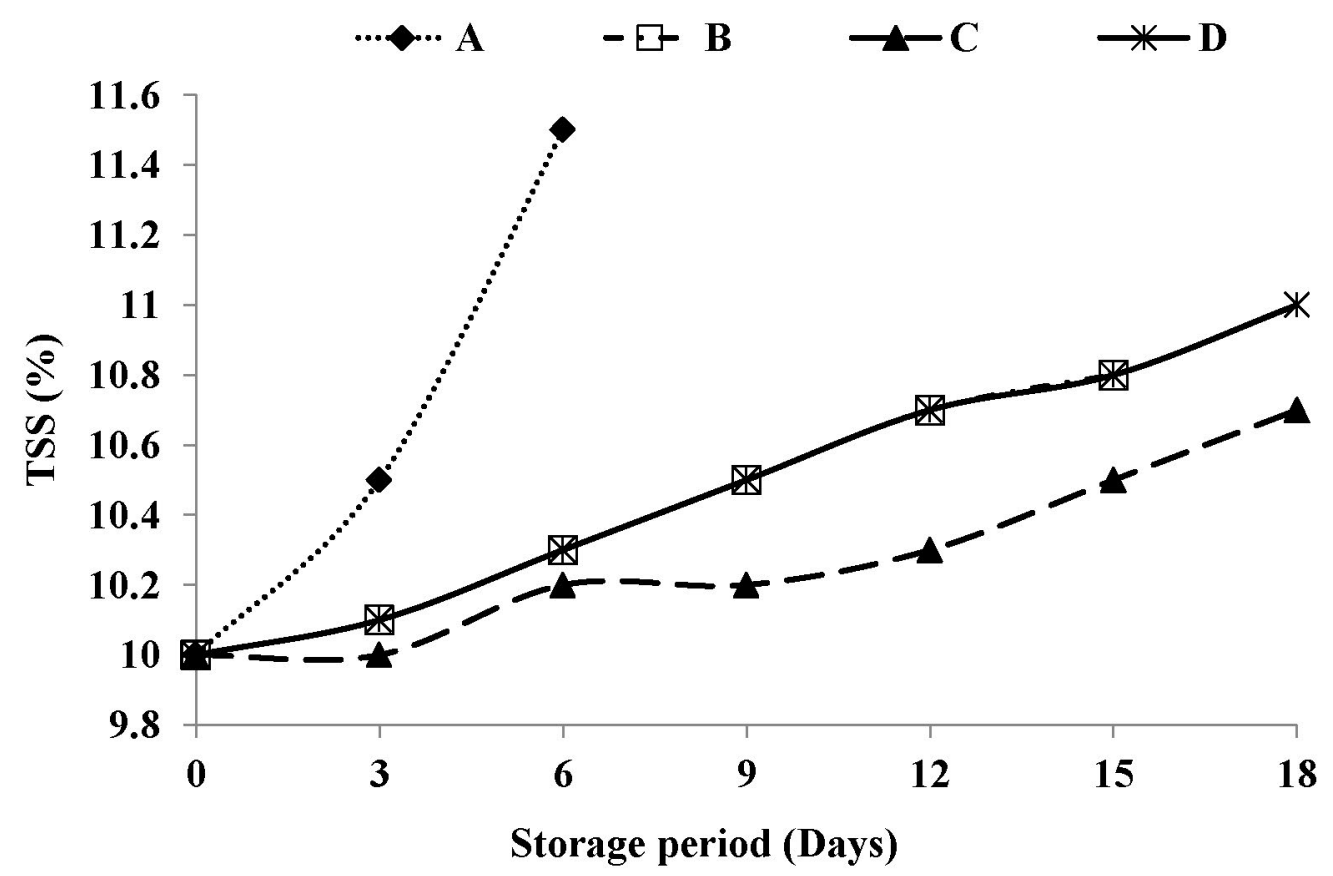

Fig. 2: Effect of coatings on TSS (\%) of guava slices during storage at $4 \pm 1^{\circ} \mathrm{C} . \mathrm{A}, \mathrm{B}, \mathrm{C}$ and D as in Fig. (1)

between all coated treatments during the storage period. The control treatment gave the highest value of TSS, while the least value was recorded by $\mathrm{C}$ coated sample $(10.7 \%)$ at the end of the storage period followed by D coated sample (11.0\%).

\section{Firmness of guava slices}

A considerable decrease in the firmness was observed during storage period of guava slices irrespective of the treatment. Antimicrobial coatings delayed slices softening and exhibited significant differences during storage. Significantly more firmness was retained by C coating followed by B \& D and the least firmness was recorded for the uncoated sample (Fig. 3). The maintenance of firmness in the coated samples with antimicrobial coatings could be due to covering of the cuticle and lenticels and their higher antifungal activity thereby reducing respiration, other ripening processes and infection during storage (Krishna \& Sudhakar 2014). The retardation of fruit softening in response to chitosan treatment was previously reported in fruits such as Indian jujube fruit (Zhong \& Xia 2007) and papaya (Raqeeb et al., 2008).

\section{Total titratable acidity (TTA\%)}

Citric acid is the major organic acid in ripe guava fruit. The TTA\% was relatively high at zero time in guava slices and then it decreased during storage period which is a natural phenomenon (Fig.
4). This might be due to rapid utilization of acids in guava fruits during the respiration process as a substrate (Gupta et al., 1979). However, there was no significant difference in TTA among all coated treatments throughout the storage period which are in favour with titratable acidity in the guava slices given by Augustin \& Christe (1989). Han et al. (2004) reported that the chitosan coating slowed down the changes in TTA of strawberry and raspberry and effectively delayed fruit ripening. The antimicrobial coating was probably able to modify the internal atmosphere of the fruit to prevent the decrease in TTA values. Therefore, the antimicrobial coatings produced a small change in TTA throughout storage. Han et al. (2004) also observed lower acidity loss during storage in strawberry, peach, tomato and litchi coated with chitosan.

\section{Vitamin C content:}

Guava contains four times more ascorbic acid as compared to citrus (Adrees et al., 2010). Vitamin $\mathrm{C}$ in guava slices gradually decreased during storage, and this reduction was effectively inhibited by edible coatings. As shown in Fig. (5), slices treated with coatings delayed the loss of vitamin C compared with the control and significant differences were recorded between them. No significant differences between all coated samples during storage until $6^{\text {th }}$ days and significant differences between them were found at $9^{\text {th }}$ to $15^{\text {th }}$ days of stor- 


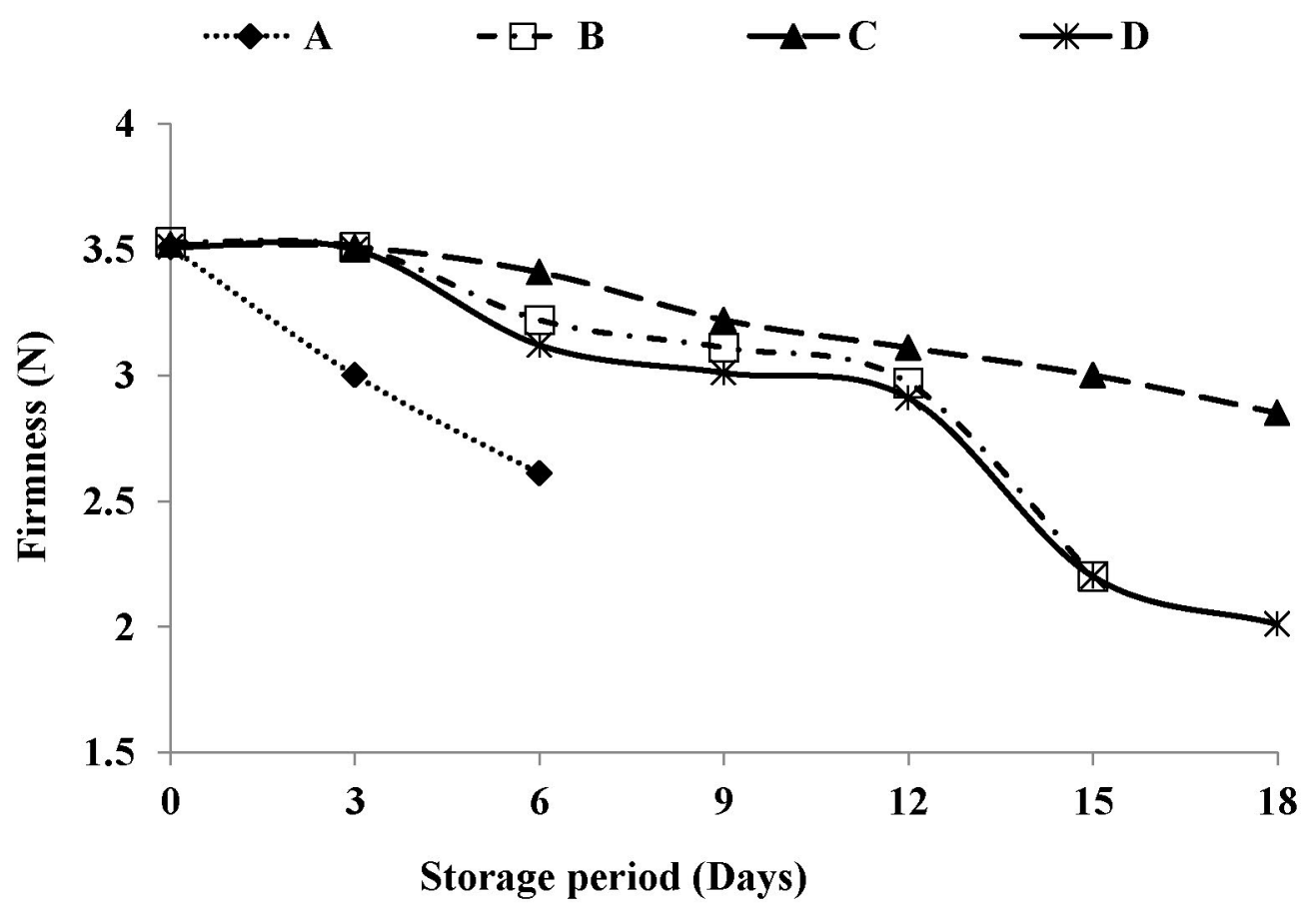

Fig. 3: Effect of coatings on firmness (N) of guava slices during storage at $4 \pm 1^{\circ} \mathrm{C} . \mathrm{A}, \mathrm{B}, \mathrm{C}$ and $D$ as in Fig. 1

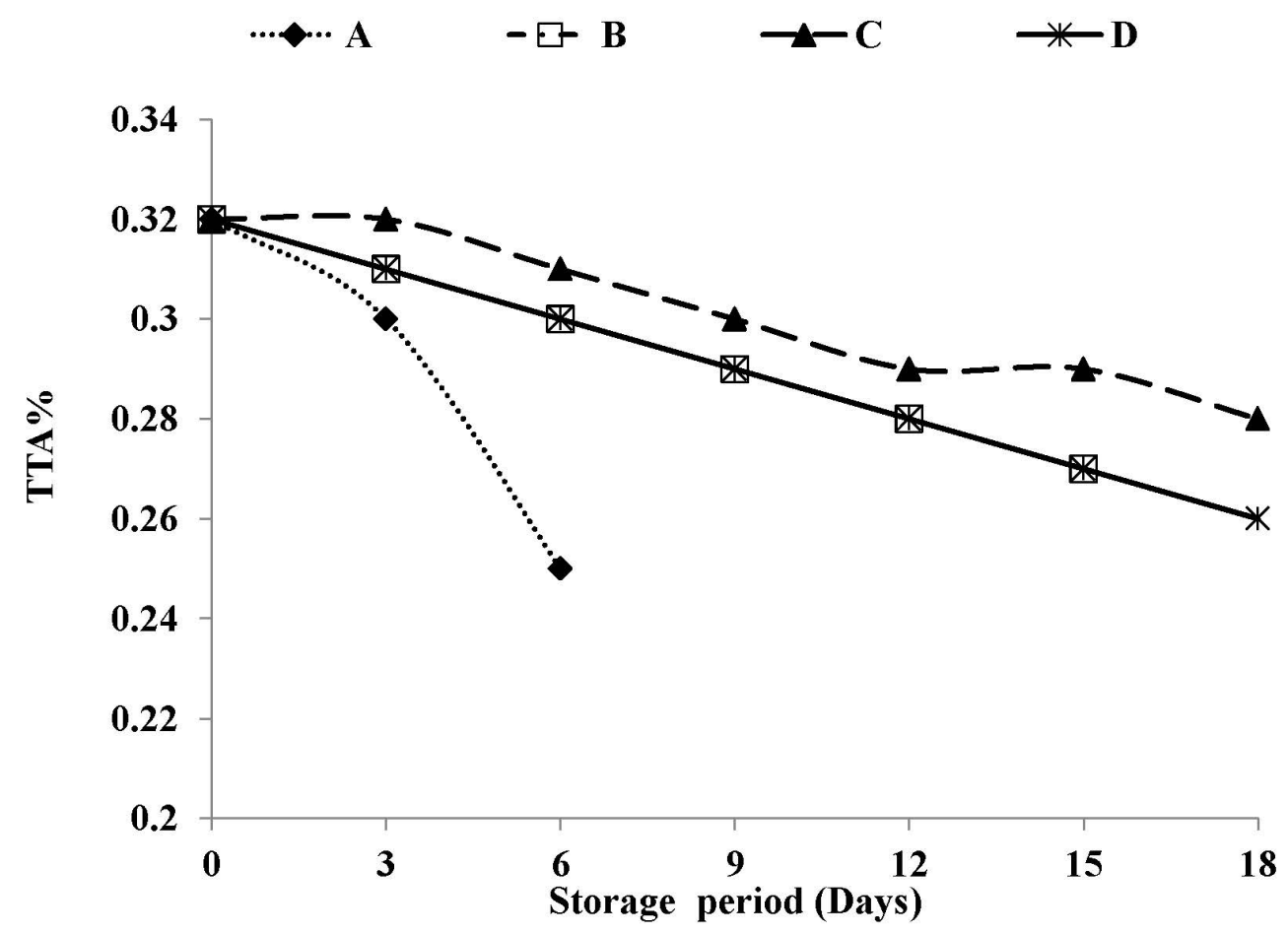

Fig. 4: Effect of coating on TTA (\%) of guava slices during storage at $4 \pm 1^{\circ} \mathrm{C} . \mathrm{A}, \mathrm{B}, \mathrm{C}$ and $D$ as in Fig. 1

age. Meanwhile, $\mathrm{C}$ treatment showed significant effect on vitamin $\mathrm{C}$ content at the same period of storage in comparison with the others. However, there was no significant effect on vitamin $\mathrm{C}$ content of guava slices due to $\mathrm{C}$ and $\mathrm{D}$ coated samples at the end of storage period. Similar results were reported by Ayranci \& Tunc (2004) who suggested that the modified atmosphere created by chitosan coating suppressed the loss of vitamin C. 


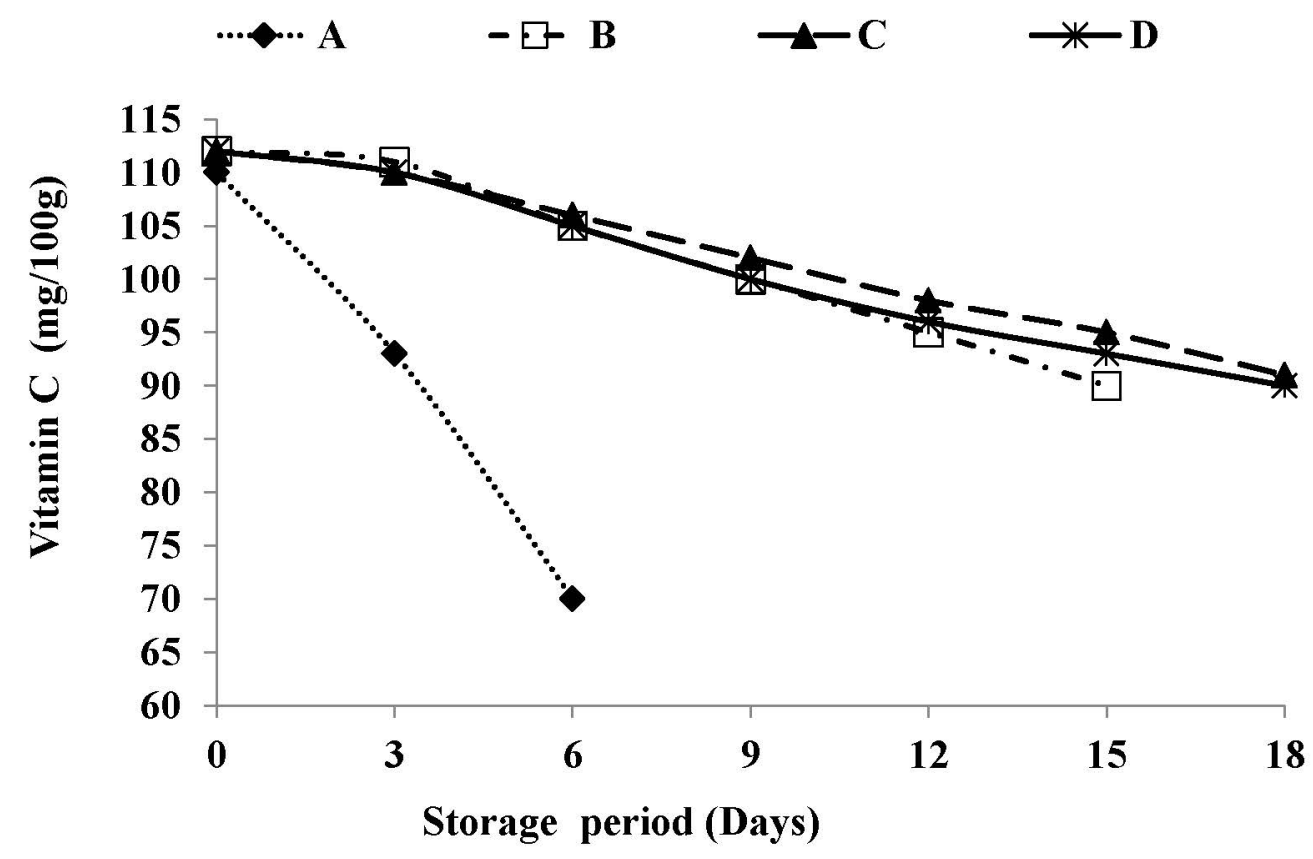

Fig. 5: Effect of coatings on vitamin $C$ content $(\mathrm{mg} / \mathbf{1 0 0 g})$ of guava slices during storage at $4 \pm 1^{\circ} \mathrm{C} . \mathrm{A}, \mathrm{B}, \mathrm{C}$ and $\mathrm{D}$ as in Fig. 1

\section{Activities of PPO and CAT}

As shown in Fig. (6), PPO activity of guava slices gradually increased during storage period. However, $\mathrm{C}$ sample as the best in decreasing the increment during storage, and significant differences were noted between it and the other treatments. This was followed by B and D samples. Antimicrobial coatings generally minimized the increase in PPO activity.

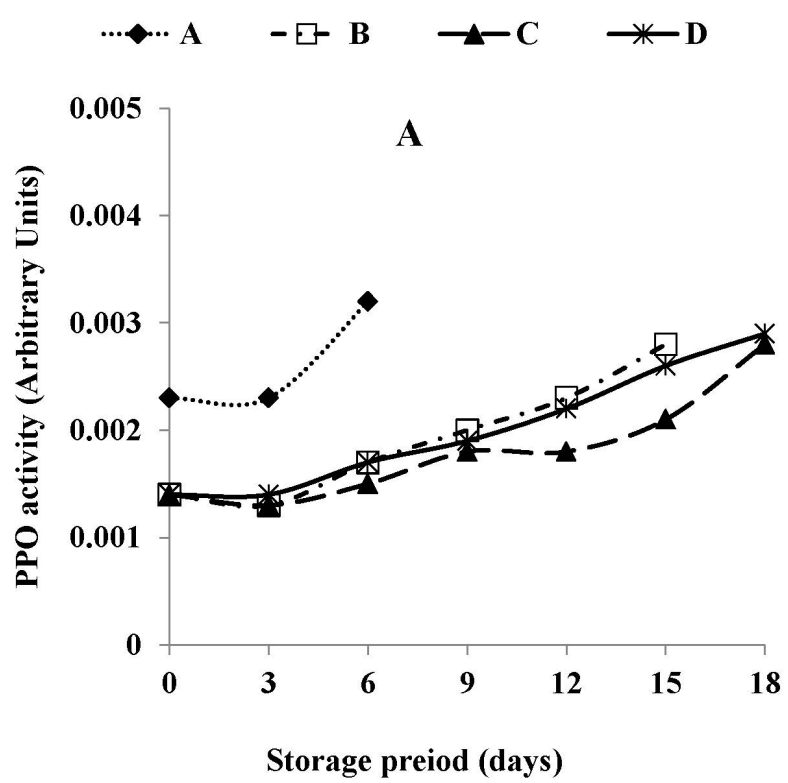

CAT activity in all samples decreased during storage period as shown in Fig. (6). However, the coating samples delayed the decrease of CAT activity. At the end of storage period, there were 32.25 and $30.56 \mathrm{U} \mathrm{g}^{-1} \mathrm{~min}^{-1}$ in CAT activity of samples treated with $\mathrm{C}$ and $\mathrm{D}$ coating, respectively. While the value of CAT activity in samples treated with $\mathrm{B}$ coating was 31.02 at $15^{\text {th }}$ day of storage compared with the control sample which had only 33.16 at $6^{\text {th }}$

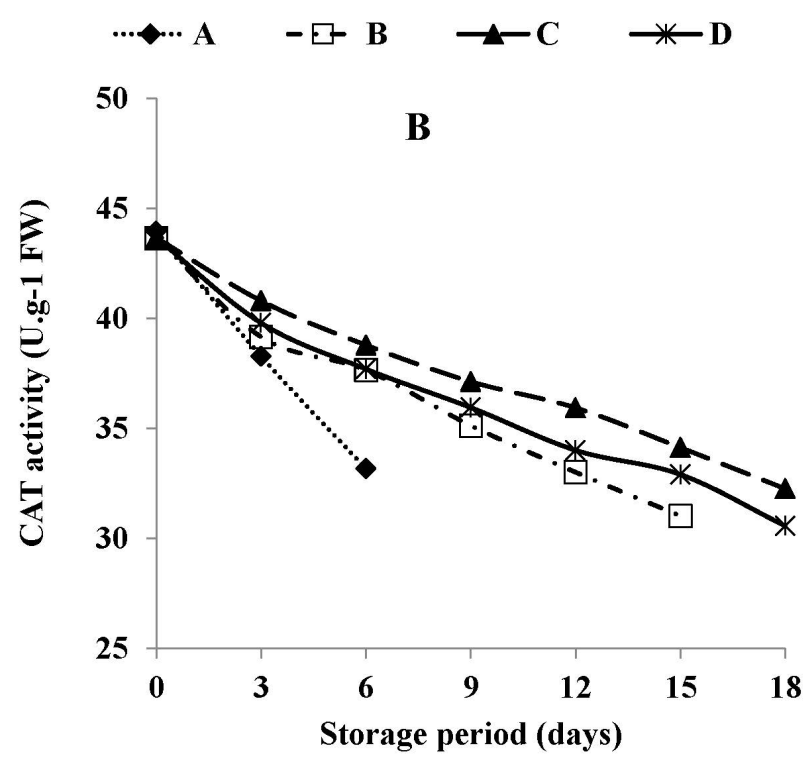

Fig. 6: Effect of coatings on polyphenol oxidase (A) and catalase (B) activities of guava slices during storage at $4 \pm 1^{\circ} \mathrm{C}$. A, B, C and $\mathrm{D}$ as in Fig. 1 
days of storage. There was also a significantly positive correlation among them. It was suggested that effect of chitosan on increase of antioxidant ability might be beneficial in delaying ripening process in guava fruit during cold storage (Hong et al. 2012). As an antioxidant enzyme, CAT plays an important role in oxidation resistant activity. Samples coated with chitosan had higher CAT activity than the control ones in the present study, indicating that the chitosan coating delayed the senescence of guava fruit.

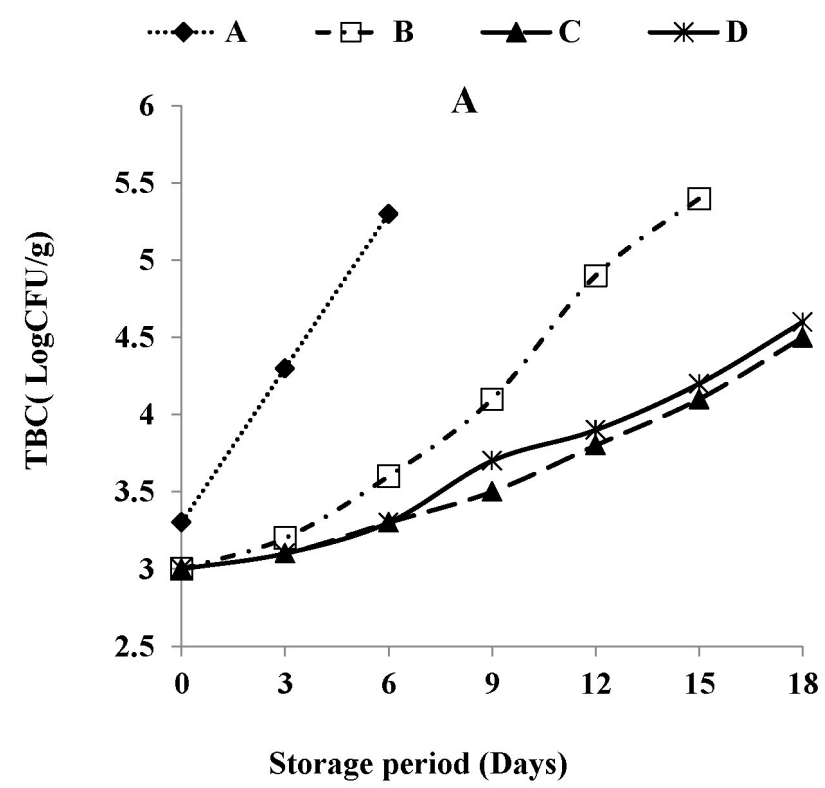

\section{Microbial growth}

According to the analysis of variance, impact of coatings and storage time was significant $(\mathrm{P}<0.05)$ on the total bacterial count and count of yeasts \& moulds. Fig. (7) shows the statistical results for the counting of the TBC and Y\&M ( $\log C F U g^{-1}$ of guava slices). The results indicated that all coatings were significantly effective in maintaining low levels of TBC compared to the control. There were significant differences between all coated and un-

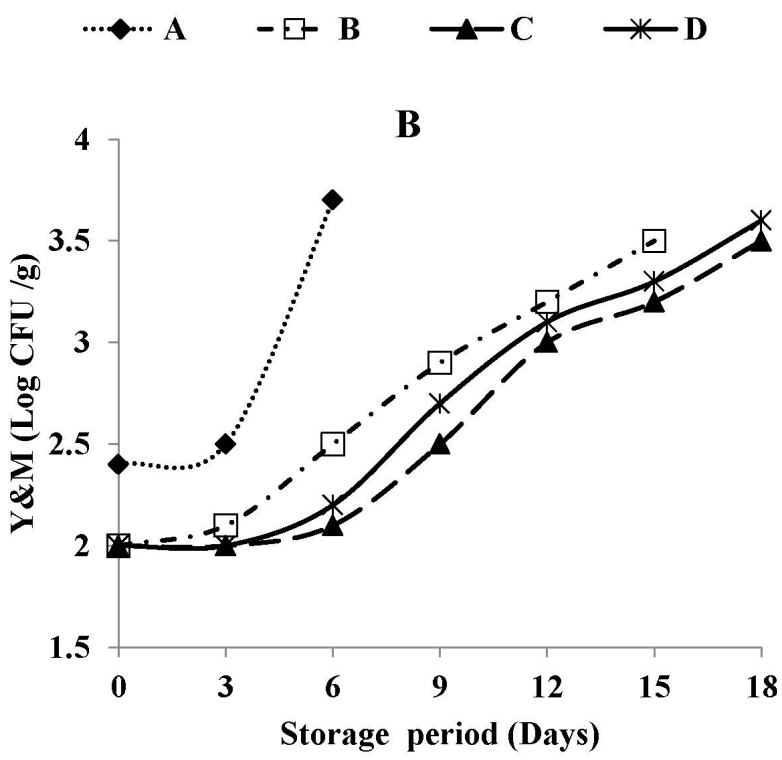

Fig. 7: Effect of coatings on TBC (A) and Y\&M count (B) of guava slices during storage at $4 \pm 1^{\circ} \mathrm{C} . \mathrm{A}, \mathrm{B}, \mathrm{C}$ and $\mathrm{D}$ as in Fig. 1

coated samples, however $\mathrm{C}$ and $\mathrm{D}$ coatings were the best among all coatings in reducing levels of TBC to 4.5 and $4.6\left(\log _{\mathrm{CFU} \mathrm{g}}{ }^{-1}\right)$ and reducing $\mathrm{Y} \& \mathrm{M}$ count to $3.5 \& 3.6\left(\log \mathrm{CFU} \mathrm{g} \mathrm{g}^{-1}\right)$ respectively at the end of storage period. These results agreed with those reported by Soares et al. (2011).

\section{Sensory evaluation}

The data presented in Table (1) show the mean values of organoleptic scores of coated and uncoated guava slices during storage. The results indicated that no significant differences in organoleptic properties were recorded among uncoated and coated samples at zero time. After that, significant differences were noted between coated and uncoated slices. Uncoated samples (control) showed significant loss of quality at $6^{\text {th }}$ days of storage, and then became unaccepted and discarded. Guava slices coated with different coatings had significant higher score than those of uncoated samples. No significant differences in scores of organoleptic qualities were noted between $\mathrm{C}$ and $\mathrm{D}$ coated samples for all attributes followed by B coated sample. At $15^{\text {th }}$ days of storage, the samples coated with B coating were unaccepted and discarded, while samples coated with $\mathrm{C}$ and D coatings were still accepted until $18^{\text {th }}$ day of storage with little changes in organoleptic qualities. Edible films can be used to protect perishable food products from deterioration by retarding dehydration, providing a selective barrier to moisture, oxygen and carbon dioxide, suppressing respiration, improving textural quality, helping retain volatile flavour compounds and reducing microbial growth (Lee et al., 2003).

\section{CONCLUSION}

The use of antimicrobial edible coatings was efficient to extend guava slices shelf-life, keeping the physical, chemical properties, enzymatic activities and microbial quality. The results suggested that 
Table 1: Effect of coatings on sensory evaluation of guava slices during storage at $4 \pm 1^{\circ} \mathrm{C}$

\begin{tabular}{|c|c|c|c|c|c|}
\hline $\begin{array}{l}\text { Storage period } \\
\text { (Days) }\end{array}$ & Attributes & & & & D * \\
\hline \multirow[t]{5}{*}{0} & Colour & $9.5 \mathrm{~A}$ & $9.8 \mathrm{~A}$ & $9.8 \mathrm{~A}$ & $9.8 \mathrm{~A}$ \\
\hline & Taste & $9.5 \mathrm{~A}$ & $9.7 \mathrm{~A}$ & $9.7 \mathrm{~A}$ & $9.7 \mathrm{~A}$ \\
\hline & Odour & $9.8 \mathrm{~A}$ & $9.9 \mathrm{~A}$ & $9.9 \mathrm{~A}$ & $9.9 \mathrm{~A}$ \\
\hline & Texture & $9.9 \mathrm{~A}$ & $9.7 \mathrm{~A}$ & $9.7 \mathrm{~A}$ & $9.7 \mathrm{~A}$ \\
\hline & Over all & $9.5 \mathrm{~A}$ & $9.7 \mathrm{~A}$ & $9.7 \mathrm{~A}$ & $9.7 \mathrm{~A}$ \\
\hline \multirow[t]{5}{*}{3} & Color & $7.5 \mathrm{~B}$ & $9.5 \mathrm{~A}$ & $9.6 \mathrm{~A}$ & $9.5 \mathrm{~A}$ \\
\hline & Taste & $7.7 \mathrm{~B}$ & $9.5 \mathrm{~A}$ & $9.5 \mathrm{~A}$ & $9.5 \mathrm{~A}$ \\
\hline & Odor & $7.5 \mathrm{~B}$ & $9.7 \mathrm{~A}$ & $9.8 \mathrm{~A}$ & $9.8 \mathrm{~A}$ \\
\hline & Texture & $7.0 \mathrm{~B}$ & $9.5 \mathrm{~A}$ & $9.6 \mathrm{~A}$ & $9.6 \mathrm{~A}$ \\
\hline & Over all & $7.5 \mathrm{~B}$ & $9.5 \mathrm{~A}$ & $9.5 \mathrm{~A}$ & $9.5 \mathrm{~A}$ \\
\hline \multirow[t]{5}{*}{6} & Colour & $5.5 \mathrm{~B}$ & $9.0 \mathrm{~A}$ & $9.2 \mathrm{~A}$ & $9.1 \mathrm{~A}$ \\
\hline & Taste & $6.2 \mathrm{C}$ & $9.0 \mathrm{~B}$ & $9.2 \mathrm{~A}$ & $9.1 \mathrm{AB}$ \\
\hline & Odour & $5.5 \mathrm{C}$ & $9.2 \mathrm{~B}$ & $9.5 \mathrm{~A}$ & $9.5 \mathrm{~A}$ \\
\hline & Texture & $6.0 \mathrm{C}$ & $9.0 \mathrm{~B}$ & $9.3 \mathrm{~A}$ & $9.3 \mathrm{~A}$ \\
\hline & Over all & $5.5 \mathrm{C}$ & $9.0 \mathrm{~B}$ & $9.4 \mathrm{~A}$ & $9.3 \mathrm{~A}$ \\
\hline \multirow[t]{5}{*}{9} & Colour & US & $8.5 \mathrm{~B}$ & $9.0 \mathrm{~A}$ & $9.0 \mathrm{~A}$ \\
\hline & Taste & US & $8.0 \mathrm{~B}$ & $8.7 \mathrm{~A}$ & $8.7 \mathrm{~A}$ \\
\hline & Odour & US & $8.0 \mathrm{~B}$ & $9.0 \mathrm{~A}$ & $9.0 \mathrm{~A}$ \\
\hline & Texture & US & $8.5 \mathrm{~B}$ & $9.0 \mathrm{~A}$ & $9.0 \mathrm{~A}$ \\
\hline & Over all & US & $8.0 \mathrm{~B}$ & $9.0 \mathrm{~A}$ & $9.0 \mathrm{~A}$ \\
\hline \multirow[t]{5}{*}{12} & Colour & US & $8.0 \mathrm{~B}$ & $8.6 \mathrm{~A}$ & $8.6 \mathrm{~A}$ \\
\hline & Taste & US & $7.7 \mathrm{~B}$ & $8.5 \mathrm{~A}$ & $8.3 \mathrm{~A}$ \\
\hline & Odour & US & $7.6 \mathrm{~B}$ & $8.7 \mathrm{~A}$ & $8.5 \mathrm{~A}$ \\
\hline & Texture & US & $7.0 \mathrm{~B}$ & $8.6 \mathrm{~A}$ & $8.5 \mathrm{~A}$ \\
\hline & Over all & US & $7.5 \mathrm{~B}$ & $8.8 \mathrm{~A}$ & $8.6 \mathrm{~A}$ \\
\hline \multirow[t]{5}{*}{15} & Colour & US & $7.8 \mathrm{~B}$ & $8.0 \mathrm{~A}$ & $8.0 \mathrm{~A}$ \\
\hline & Taste & US & $7.5 \mathrm{~B}$ & $8.1 \mathrm{~A}$ & $8.1 \mathrm{~A}$ \\
\hline & Odour & US & $7.2 \mathrm{~B}$ & $8.5 \mathrm{~A}$ & $8.5 \mathrm{~A}$ \\
\hline & Texture & US & $6.7 \mathrm{~B}$ & $8.3 \mathrm{~A}$ & $8.1 \mathrm{~A}$ \\
\hline & Over all & US & $6.5 \mathrm{~B}$ & $8.5 \mathrm{~A}$ & $8.4 \mathrm{~A}$ \\
\hline \multirow[t]{5}{*}{18} & Colour & US & US & $7.3 \mathrm{~A}$ & $7.2 \mathrm{~A}$ \\
\hline & Taste & US & US & $7.8 \mathrm{~A}$ & $7.7 \mathrm{~A}$ \\
\hline & Odour & US & US & $8.0 \mathrm{~A}$ & $8.0 \mathrm{~A}$ \\
\hline & Texture & US & US & $7.5 \mathrm{~A}$ & $7.5 \mathrm{~A}$ \\
\hline & Over all & US & US & $7.8 \mathrm{~A}$ & $7.8 \mathrm{~A}$ \\
\hline
\end{tabular}

Averages with different superscripts in each row differed significantly $(\mathrm{P} \leq 0.05)$, US: unaccepted slices - * A, B, C and $\mathrm{D}$ as in Fig. (1) 
coatings with potato starch and chitosan provied an antimicrobial effect on total bacterial count and yeast and moulds count. The use of an edible coating in association with natural antimicrobials is a good way to increase fruit slices shelf-life.

\section{REFERENCES}

Adrees, M., Younis, M., Farooq, U. \& Hussain, K. 2010. Nutritional quality evaluation of different guava varieties. Pakistan Journal Agriculture Science, 47: 1-4.

Aebi, H. 1984. Catalase in vitro. Methodes Enzymes., 105: 121-126.

AOAC 2000. Association of Official Analytical Chemists. 17th Edition Washington DC.

Augustin, M. A. \& Christe, H. C. 1989. Effect of different temperature on the storage life of guava. Journal Japan. Society Food Science Technology, 31:495-498.

Ayranci, E. \& Tunc, S., 2004. The effect of edible coatings on water and vitamin $\mathrm{C}$ loss of apricots (Armeniaca vulgaris L.) and green peppers (Capsicum annum L.). Food Chemistry 87: 339-342.

Bassetto, E., Jacomino, A. P., Pinheiro, A. L. \& Kluge, R. A. 2005. Delay of ripening of 'Pedro Sato' guava with 1-methylcyclopropene. Postharvest Biology Technology, 35:303308.

Benet, S., Ducruet, V. \& Feigenbaum, A. 1992. Securite et qualite des emballages alimentaires: etude des interactions de bouchons en polyethylene haute densite avec des substances organiques volatiles Analysis, 20: 391-396.

Blumental, M. M. 1997. How food packaging affects food flavor. Food Technology, 51:7174.

Difco Manual 1977. Dehydrated Culture Media and Reagents for Microbiological and Clinical Laboratory Procedures. 9th Ed., Detroit, Michgan, USA.

Dong, H., Cheng, L., Tan, J., Zheng, K. \& Jiang, Y., 2004. Effect of chitosan coating on quality and shelf-life of peeled litchi fruit. Journal Food Engineering 64: 355-358.

Elabd, M. A. 2013. Production and Evaluation of Edible Films for Coating Fresh Fruits and Vegetables. Ph.D Thesis, Faculty Agriculture, Kafer El-Sheikh University Egypt.
El-Ghaouth A., Smilanick, J. L. \& Wilson, C. L. 2000. Enhancement of the performance of candida saitoana by the addition of glycol chitosan for the control of postharvest decay of apple and citrus fruit. Postharvest Biology and Technology, 19:103-110.

Gupta, O. P., Singh, B. P. \& Gupta, A. K. 1979. Studies on the shelf life of different guava cultivars. Journal of Research - Haryana Agricultural University, 9: 247-50.

Hafez, Y. M. 2010. Control of Botrytis cinerea by the resistance inducers benzothiadiazole (BTH) and hydrogen peroxide on white pepper fruits under postharvest storage. Acta Phytopathol Entomol Hung., 45:13-29.

Han, C., Zhao, Y., Leonard, S. W. \& Traber, M. G. 2004. Edible coatings to improve storability and enhance nutritional value of fresh and frozen strawberries (Fragaria ananassa) and raspberries (Rubus idaeus). Postharvest Biology and Technology, 33: 67-78.

Hassimotto, N. M., Genovese, M. I. \& Lajolo. F. M. 2005. Antioxidant activity of dietary fruits, vegetables, and commercial frozen fruit pulps. Journal of Agriculture and Food Chemistry, 53: 2928-2935.

Hong, K., Xie, J., Zhang, L., Sun, D. \& Gong, D. 2012. Effects of chitosan coating on postharvest life and quality of (Psidium guajava $\mathrm{L}$.) fruit during cold storage. Scientia Horticulturae 144: $172-178$

Jiang, Y. M. \& Li, Y. B. 2001. Effects of chitosan coating on postharvest life and quality of longan fruit. Food Chemistry, 73: 139-143.

Krishna, R. K. \& Sudhakar, R. D. V. (2014). Effect of Chitosan Coating on the Physiochemical Characteristics of Guava (Psidium guajava L.) Fruits During Storage at Room Temperature. Indian Journal of Science and Technology, 7: 554-558.

Lawless, H. T. \& Heymann, H. 1999. Sensory evaluation of food: principles and practices. Gaithersburg, ML: Aspen Publishers, Inc. $825 \mathrm{p}$.

Lee, J., Park, H., Lee, C. \& Choi, W. 2003. Extending shelf life of minimally processed apples with edible coatings and antibrowning agents. Swiss Society of Food Science and Technology, 36: 323-329. 
Lemos, O. L., Reboucas, T. N., Jose, A. R., Vila, M. T. \& Silva, K. S. 2007. Utilizacao de biofilme comestivel na conservacao de pimentao 'Magali R'em duas condicoes de armazenamento. Bragantia, 66: 693-699.

Lima, M. A., de-Assis, J. S. \& de-Gonzaga N. L. 2002. Caracterizacao dos frutos de goiabeira - selecao de cultivares na Regiao do Submedio Sao Francisco. Revista Brasileira de Fruticultura, 24: 273-276.

Liu, J., Tian, S., Meng, X. \& Xu, Y. 2007. Effects of chitosan on control of postharvest diseases and physiological responses of tomato fruit. Postharvest Biology and Technology, 44: 300-306.

Malik, C. P. \& Singh, M. B. 1980. Plant enzymology and histo-enzymology: A text manual In: Plant Emynology and Histon enzymology. Kalyani Publishers. Delhi pp.54-56.

Nasution, Z., Wei Ye, J. N. \& Hamzah, Y. 2015. Characteristics of fresh-cut guava coated with aloe vera Gel as affected by different additives. Kasetsart Journal Natural Science, 49: 111-121.

Oms-Oliu, G., Rojas-Grau, M. A., Gonzalez, L. A., Varela, P., Soliva-Fortuny, R., Hernando, M. I., Munuera, H., Fiszman I. P. \& MartinBelloso, O. 2010. Recent approaches using chemical treatments to preserve quality of fresh-cut fruit: A review. Postharvest Biology and Technology, 57: 139-148.

Raqeeb, A. A., Mahmud, T. M., Omar, S. R. \& Zaki, A. R. 2008. Effect of calcium infiltration and chitosan coating on storage life and quality characteristics during storage of papaya (Carica papaya L.). International Journal of Agricultural Research, 3: 296-306.

Raybaudi-Massilia, R. M., Mosqueda-Melgar, J., Sobrino-Lopez, A., Soliva-Fortuny, R. \& Martin-Belloso, O. 2007. Shelf-life extension of fresh-cut "Fuji" apples at different ripe- ness stages using natural substances. Postharvest Biology and Technology, 45: 265-275.

Reineccius, G. 1991. Off-flavors in foods. C.R. Food Science and Nutrition, 29: 381-402.

Rojas-Grau, M. A., Oms-Oliu, G. Soliva- Fortuny, R. \& Martin-Belloso O. 2009. The use of packaging techniques to maintain freshness in fresh-cut fruits and vegetables: A review. Int. Journal of Food Science and Technology, 44: $875-889$.

SAS Institute 2010. User,s Guids: version 9.22. SAS Institute, Inc., Cary, NC, USA.

Soares, N. F., Silva, D. F., Camilloto, G. P., Oliveira, C. P., Pinheiro, N. M. \& Medeiros, E. A. 2011. Antimicrobial edible coating in post-harvest conservation of guava. Revista Brasileira de Fruticultura, 33: 281-289.

Tan, S. C., Tan, T. K., Wong, S. M. \& Khor, E. 1996. The chitosan yield of zygomycetes at their optimum harvesting time. Carbohydrate Polymers, 30: 239-242.

Vila M. T., Lima, L. C., Vilas Boas, E. V., Hojo, E. T., Rodrigues, L. J. \& Paula, N. R. 2007. Caracterizacao quimica - bioquimica de goiabas armazenadas sob refrigeracao - atmosfera modificada. Ciencia-Agrotecnologia, $\mathbf{3}$ : 1435-1442.

Watada, A. E. \& Qi, L. 1999. Quality of fresh-cut produce. Postharvest Biology and Technology, 15: 201-205.

Zhong, Q. \& Xia, W. 2007. Effect of 1-methylcyclopropene and/ or chitosan coating treatments on storage life and quality maintenance of Indian jujube fruit. Food Science and Technology, 40: 404-411.

Zhu, X., Wang, Q. M., Cao, J. K. \& Jiang, W. B. 2008. Effects of chitosan coating on postharvest quality of mango (Mangifera indica L.CV. Tainong) fruits. Journal of Food Process and Preservation, 32: 770-784. 


\title{
تأثير الأغشية الطبيعية المضادة للميكروبات

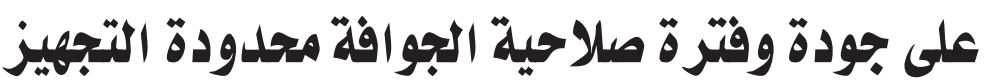

\author{
منى أحمد عبدالعاطى العبد \\ قسم بحوث هندسة التصنيع والتعبئة والتغليف، معهد بحوث تكنولوجيا الأغذيه، \\ مركز البحوث الزراعيه، الجيزة
}

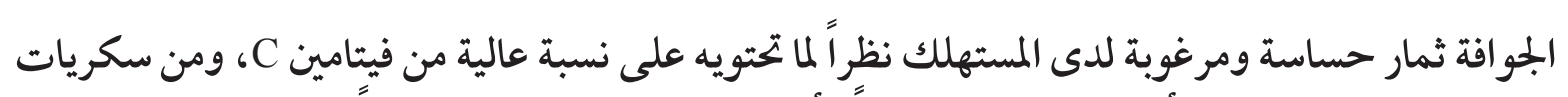

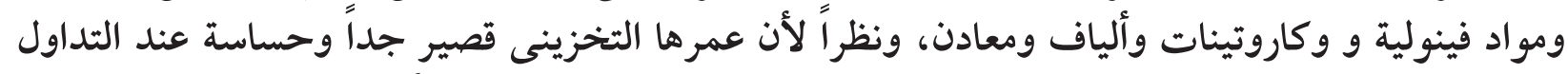

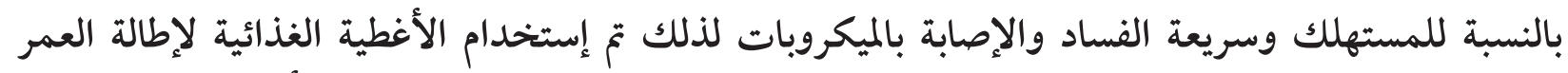

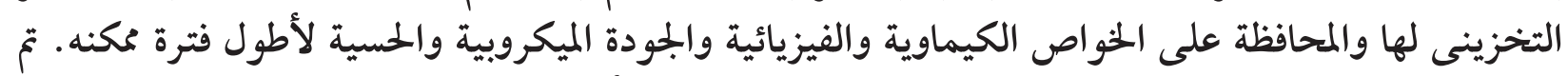

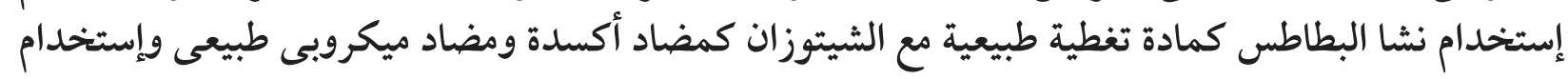

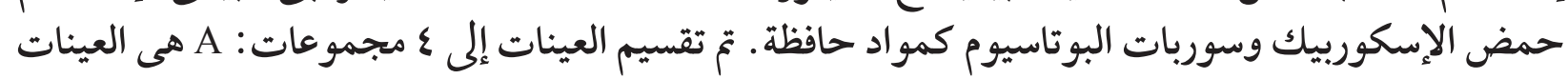

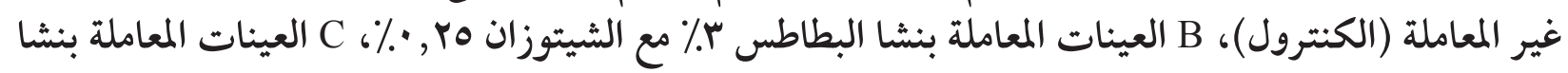

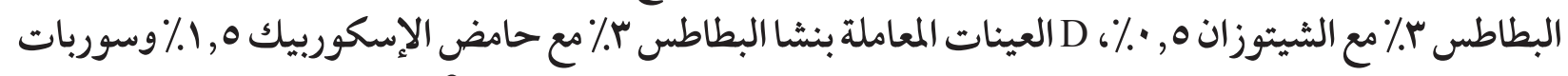

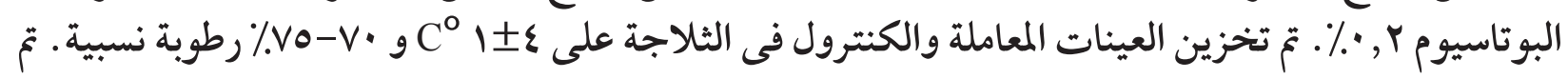

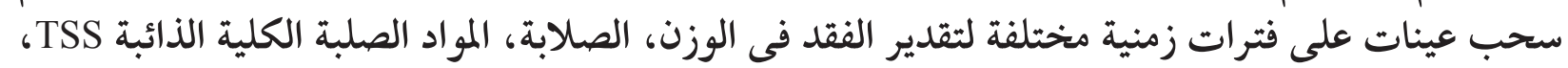

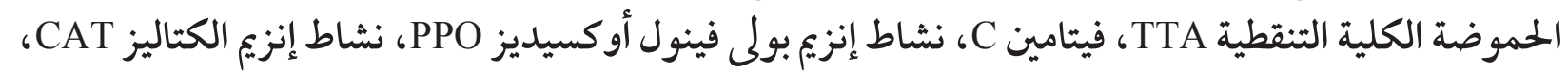
الحمل الميكروبى والخو اص الحسية.

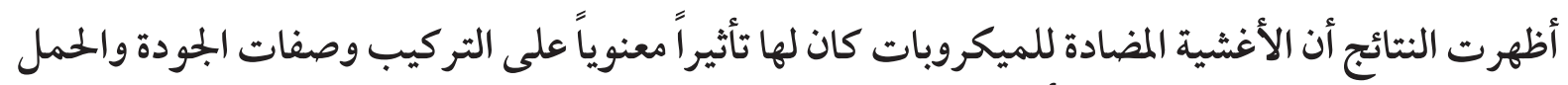

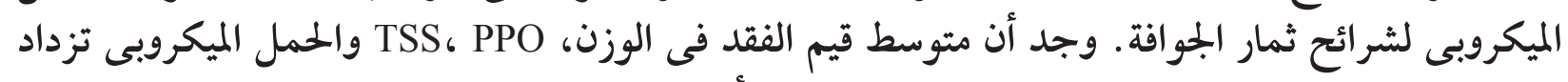

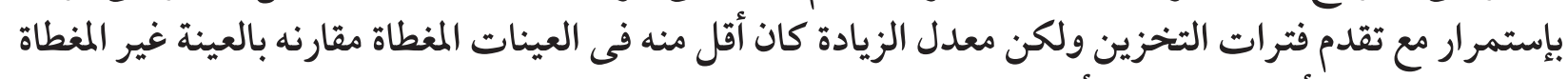

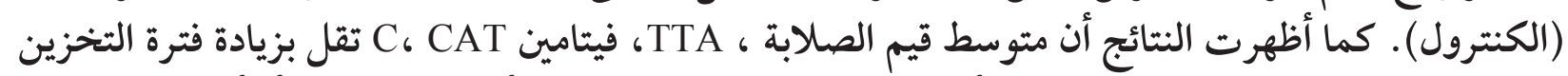

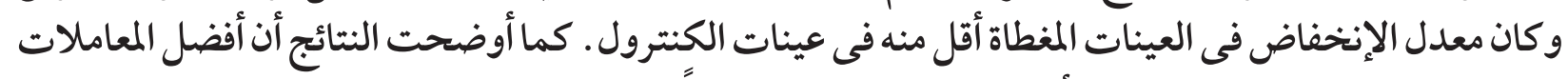

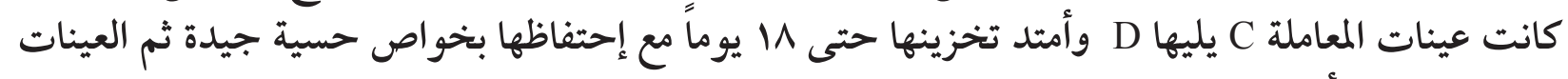

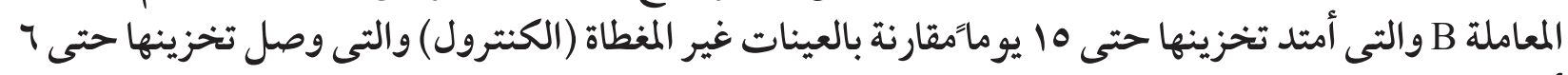
أيام فقط ثم فسدت بعد ذلك . 
